\title{
FIRST REPORT OF LINGUADACTYLOIDES BRINKMANNI (MONOGENOIDEA: LINGUADACTYLOIDINAE) ON HYBRIDS OF COLOSSOMA MACROPOMUM X PIARACTUS BRACHYPOMUS (CHARACIDAE) FROM SOUTH AMERICA
}

\author{
DIAS, M. K. R. ${ }^{1}$, TAVARES-DIAS, M..$^{*} \&$ MARCHIORI, N. ${ }^{3}$ \\ 1 - Programa de Pós-Graduação em Biodiversidade Tropical (PPGBio), Universidade Federal do \\ Amapá (UNIFAP), Macapá, AP, Brasil. \\ 2 - Laboratório de Aquicultura e Pesca, Embrapa Amapá, Macapá, AP, Brasil. \\ 3 - Laboratório de Sanidade de Organismos Aquáticos, Universidade Federal de Santa Catarina \\ (UFSC), Florianópolis, SC, Brasil. \\ *Corresponding author: Marcos Tavares-Dias. Embrapa Amapá, Rodovia Juscelino Kubitschek, km 5, \\ № 2600,68903-419, Macapá, AP, Brazil. E-mail: marcos.tavares@embrapa.br
}

\begin{abstract}
Dias, M. K. R., Tavares-DIAS, M. \& Marchiori, N. (2012) First report of Linguadactyloides brinkmanni (Monogenoidea: Linguadactyloidinae) on hybrids of Colossoma macropomum x Piaractus brachypomus (Characidae) from South America. Braz. J. Aquat. Sci. Technol. 16(2):61-64. eISSN 1983-9057. This study presents the first report of infection by Linguadactyloides brinkmanni Thatcher \& Krytsky, 1983 (Monogenoidea, Dactylogyridae, Linguadactyloidinae) on the gills of hybrid tambatinga (Colossoma macropomum x Piaractus brachypomus) from fish farms from the city of Macapá, state of Amapá, Brazil. Out of 201 hybrid tambatinga examined, ten were infected by L. brinkmanni (prevalence $=4.9 \%$ ). From these hosts, 21 specimens of $L$. brinkmanni were collected and the mean intensity of infection was 2.1 (1-4 parasites/ host). This study expands the distribution of this monogenoidean for a new host.
\end{abstract}

Key-words: Dactylogyridae, Freshwater fish, Infection, Parasite

The hybrid tambatinga results from the crossbreeding of Colossoma macropomum Cuvier, $1818 \mathrm{x}$ Piaractus brachypomus Cuvier, 1818. It is a large fish species, reaching up to $80 \mathrm{~cm}$ in length and more than $15 \mathrm{~kg}$ total weight (Cruz et al., 2006). This hybrid fish is superior in growth and productivity when compared with its parental species (Hashimoto et al., 2012). Due to such zootechnical features the tambatinga has been cultured both in Brazil (Cruz et al., 2006; Lopera-Barrero et al., 2011) and Venezuela (SilvaAcuna \& Guevara, 2002). In Brazil, tambatinga is the major hybrid fish of interest to aquaculture (Hashimoto et al., 2012). In 2010, the production of this fish was $4.915,6$ tons, $28.5 \%$ higher than the one recorded in 2008 (MPA, 2012). However, in Brazilian cultures, the parasitic fauna of hybrid tambatinga has not been yet investigated. Parasites cause problems of diseases and economic loss for the country's fish farmers. This study reports the occurrence of monogenoideans species in farmed hybrid tambatinga in Brazilian Amazon.

From July 2009 to March 2011, two hundred and one specimens of hybrid tambatinga (27.2 \pm 3.0 $\mathrm{cm}$ and $652.4 \pm 16.0 \mathrm{~g}$ ) were collected from three different fish farms from city of Macapá, state of Amapá, eastern Amazon, (Brazil). Fish were necropsied and their gills were fixed in $5 \%$ formalin for posterior analysis. The collected parasites were prepared in Hoyer's solution for observation of the sclerotized structures and also stained with Gomori trichrome (Eiras et al. 2006; Thatcher, 2006), and identified according to Thatcher \& Krytsky (1983). Ecological terminology follows Bush et al. (1997). Ten specimens of tambatinga (Table 1 ) had the gills parasitized by Linguadactyloides brinkmanni Thatcher \& Krytsky, 1983 (Monogenoidea, Dactylogyridae, Linguadactyloidinae). The Figure 1 shows all the structures used for the identification of monogenoidean species. This is the first report of $L$. brinkmanni parasitizing tambatinga from the South America.

Linguadactyloides brinkmanni has been reported in Brazil, Cuba and Venezuela (Kohn \& Cohen, 1998; Cohen \& Kohn, 2008; Cohen \& Kohn, 2009), associated with both natural and cultured populations of C. macropomum (Thatcher \& Krytsky, 1983; Prieto, 1989; Ceccarelli et al., 1990; Aragot \& Moreno, 1997; Aragort et al., 2002; Fisher et al., 2003; Varella et al., 2003; Fisher et al., 2003; Cohen \& Kohn, 2009; Morais et al., 2009). These results suggest that even though this is a neotropical parasite of characids Serrasalminae species, it also parasites the hybrids resulting from C. macropomum. The present study expands the distribution of these monogenoidean by presenting the hybrid tambatinga. 

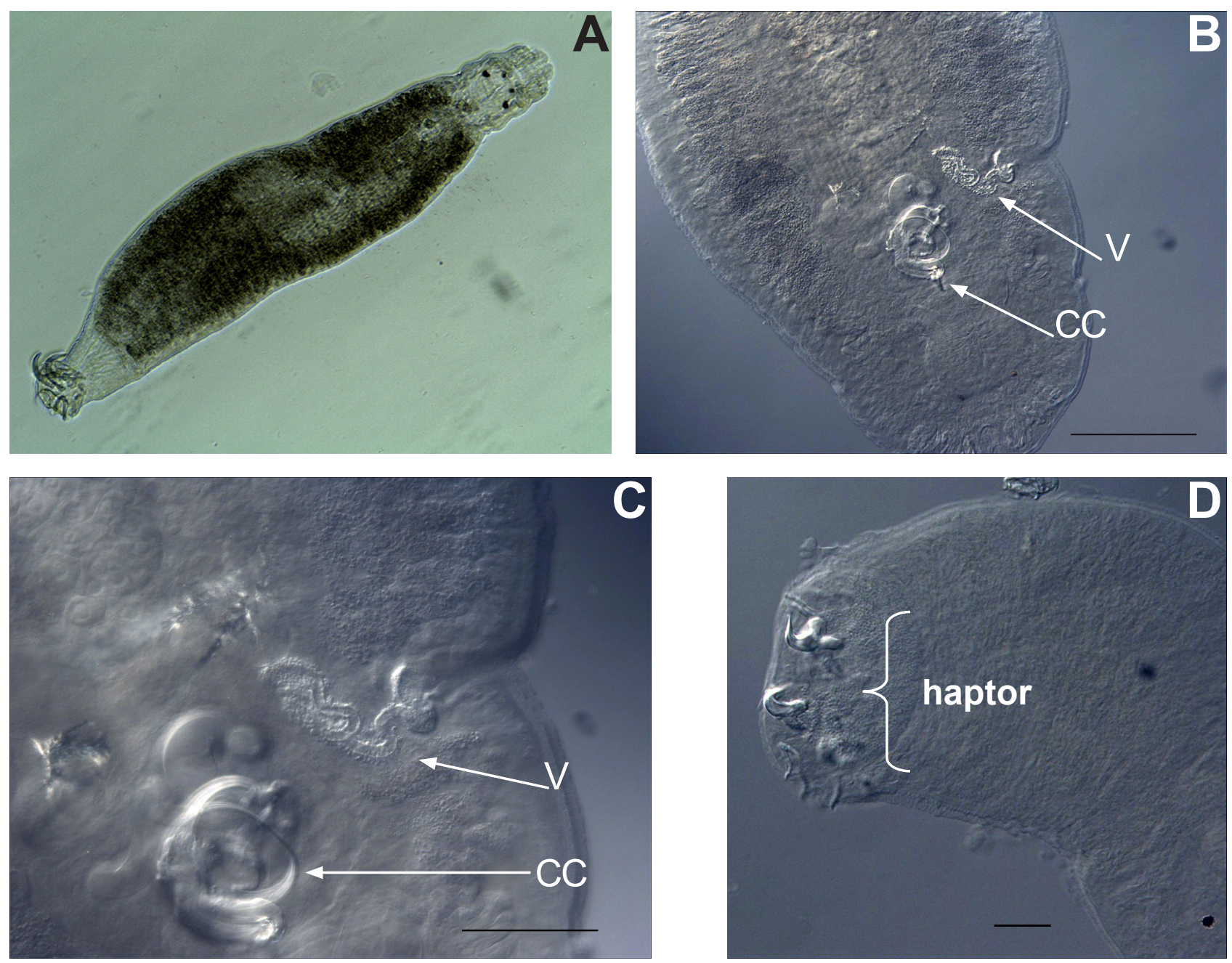

Figure 1 - Linguadactyloides brinkmanni (A) on the gills of hybrid tambatinga from fish farms from the state of Amapá, eastern Amazon, Brazil. Bar $=300 \mu \mathrm{m}$. Copulatory complex (CC) and vagina (V) (B-C): Bar= 140 and $130 \mu \mathrm{m}$, respectively. Haptor (D) with anchor and hook: Bar $=45 \mu \mathrm{m}$. Phase contrast technique.

This monogenoidean species is highly pathogenic to its host since its penetration in the gill filaments (possibly reaching the cartilage of the gill filament) causes severe inflammatory reaction and serious gill hyperplasia accompanied by hemorrhage on the sites of attachment (Thatcher \& Krytsky, 1983; Aragort et al., 2002; Thatcher, 2006). Thatcher (2006) reported that $L$. brinkmanni ingests epithelium cells as well as red blood cells; hence, in general, it can be observed in red color when examined to microscopy. In fact, in the present study, the presence of red hemoglobin pigment was observed inside L. brinkmanni, corroborating with the findings of the aforementioned author. This also suggests that a high level of infection by monogenoidean species can lead to severe fish anemia, which may represent a danger to farmed fish. It can also cause a general stress response with potentially harmful effects to these fish.

Analysis of parasitological indexes showed $L$. brinkmanni prevalence of $4.9 \%$ and mean intensity of infection of 2.2 parasites/host (Table 1). Besides L. brinkmanni, it was also registered the presence of Anacanthorus spathulatus Kritsky, Thatcher \& Kayton, 1979, which dominated the monogenoideans community on the hosts' gills (prevalence $=79.1 \%$ and mean intensity $=126$ parasite/host). Centeno et al. (2004) also found $A$. spathulatus infesting the hybrid tambatinga cultured in Venezuela (prevalence of $72.6 \%$ ), but no presence of $L$. brinkmanni. For $C$. macropomum farmed in cages, Morais et al. (2009) reported $A$. spathulatus (prevalence $=100 \%$ and mean intensity $=57.3$ ), Mymarothecium boegeri Cohen \& Kohn, 2005 (prevalence $=71.4 \%$ and mean intensity = 3.4), Notozothecium janauachensis Belmont-Jegu, Domingues \& Laterça, 2004 (prevalence $=85.7 \%$ and mean intensity $=5.8$ ), and L. brinkmanni (prevalence $=14.3 \%$ and mean intensity $=1.1$ ), respectively. However, gill-infecting dactylogyrid monogenoideans commonly exhibit a narrow site-specificity. Due the competition among the species by a same niche on 
Table 1 - Parasitological indexes for Linguadactyloides brinkmanni on the gills of hybrid tambatinga of fish farms from the state of Amapá, eastern Amazon, Brazil.

\begin{tabular}{lc}
\hline \hline Parameters & Linguadactyloides brinkmanni \\
\hline Examined fish & 201 \\
Infected fish & 22 \\
Prevalence $(\%)$ & 4.9 \\
Mean intensity & 2.1 \\
Range of intensity & $1-4$ \\
Mean abundance & 0.1 \\
Total number of parasites & 21 \\
\hline \hline
\end{tabular}

the host's gills, monogenoidean-fish host systems are extremely varied and diverse (Soler-Jiménez \& FajerÁvila, 2012), and dependents of monogenoideans species.

Variation in infection levels of monogenoideans can be associated to seasonal changes in water temperature, which directly affects the reproduction, survival time and behavior of parasites species. It can be also affected by size and development of the host fish and by ecological and morphological differences between monogenoideans species (Soler-Jiménez \& Fajer-Ávila, 2012). In present study, fish 5.0-49.0 $\mathrm{cm}$ long were examined, yet $L$. brinkmanni was only found in fish between 21.0 and $45.0 \mathrm{~cm}$ of length. This survey was carried out from July 2009 to March 2011 (rainy and dry season). Infection by L. brinkmanni occurred in February, March (rainy season), October and November (dry season). Hence, there was no seasonal pattern in infection by this neotropical monogenoidean. Further studies on the infracommunity composition and also competition among the monogenoideans species are necessary for understanding this parasite-host relationship.

\section{ACKNOWLEDGEMENTS}

The authors thank the National Council of Scientific and Technological Development/CNPq (\# 578159/2008-2) for financial support.

\section{REFERENCES}

Aragort, W.C. \& Moreno, L.G. 1997. Índices epidemiológicos de trematodos monogenésicos em brânquias de Colossoma macropomum banjo de cultivo. Acta Biol. Venez. 17 (1): 1-8.

Aragort, W.; Morales, G.; León, E.; Pino L.A.; Guillén, A. \& Silva, M. 2002. Patologías asociadas a monogeneos branquiales em cachama bajo cultivo. Vet. Trop. 27 (2): 75-85.
Bush, A.O.; Lafferty, K.D.; Lotz, J.M. \& Shostak, W. 1997. Parasitology meets ecology on its own terms: Margolis et al. Revisited. J. Parasitol. 83: 575-583.

Centeno, L.; Silva-Acunã, A.; Silva-Acunã, R. \& Pérez, J.L. 2004. Fauna ectoparasitaria associada a Colossoma macropomum y al híbrido de $C$. macropomum x Piaractus brachypomus, cultivados em el Estado Delta Amacuro, Venezuela. Bioagro 16 (2): 121-126.

Ceccarelli, P. S; Figueira, L. B.; Ferraz-Lima, C. L. B. \& Oliveira, C. A. 1990. Observação de ocorrência de parasitos no Cepta entre 1983 e 1990. Bol. Tec. Cepta Pirassununga 3: 43-54.

Cohen, S.C. \& Kohn, A. 2008. South American Monogenea - list of species, hosts and geographical distribution from 1997 to 2008. Zootaxa, 1924: $1-42$.

Cohen, S.C. \& Kohn, A. 2009. On Dactylogyridae (Monogenea) of four species of characid fishes from Brazil. Check List 5 (2): 351-356.

Cruz, A.G.; Melo, A.E.E.F.; Sobreira, C.B.; Mazeto, M.D. \& Naoe, L.K. 2006. Densidade $x$ biomassa: piscicultura. Seagro Boletim Técnico, Palmas (TO), 13p.

Eiras, J.C.; Takemoto, R.M. \& Pavanelli, G.C. 2006. Métodos de estudo e técnicas laboratoriais em parasitologia de peixes. $2^{\mathrm{a}}$ Ed. Eduem, Maringá, $199 p$.

Fischer, C.; Malta, J.C.O. \& Varella, A.M.B. 2003. Fauna parasitaria do tambaqui Colossoma macropomum (Curvier,1818) (Characiformes: Charicidae) do médio Rio Solimões, estado do Amazonas (AM) e do baixo Rio Amazonas estado do Pará (PA), e seu potencial como indicadores biológicos. Acta Amazonica 33 (4): 651-662.

Hashimoto, D.T.; Senhorini, J.A.; Foresti, F. \& PortoForesti, F. 2012. Interspecific fish hybrids in Brazil: management of genetic resources for sustainable use. Rev. Aquacult. 4: 108-118.

Kohn, A. \& Cohen, S.C. 1998. South American Monogenea - List of species, hosts and 
geographical distribution. Inter. J. Parasitol. 28: 1517-1554.

Lopera-Barrero, N.M.; Ribeiro, R.P.; Povh, J.A.; Vargas, L.D.M.; Poveda-Parra, A.R.; Digmayer, M. 2011. As principais espécies produzidas no Brasil. In: Lopera-Barrero, N.M. et al. (ed.). Produção de organismos aquáticos: uma visão geral no Brasil e no mundo. Agrolivros, Guaíba. 143-215pp.

Morais, A.M.; Varella, A.M.B.; Correa, M. A.V. \& Malta, J.C.O. 2009. Fauna de parasitos em juvenis de tambaqui Colossoma macropomum (Cuvier, 1818)

(Characidade: Serrasalminae) criados em tanquesrede em lago de várzea da Amazônia central. Biol. Geral Exper. 9 (1): 14-23.

Prieto, A. 1989. Hallazgos de monogeneas parásitos de Colossoma macropomum. Efecto sobre el huésped. Rev. Salud Anim. 11: 78-81.

Silva-Acuna, A. \& Guevara, M. 2002. Evolución de las dietas comerciales sobre el crescimento de híbrido de Colossoma macropomum x Piaractus brachypomus. Zootec. Trop. 20 (4): 449-459.

Soler-Jiménez, I.C. \& J. Fajer-Ávila, E.J. 2012.The microecology of dactylogyrids (Monogenea:
Dactylogyridae) on the gills of wild spotted rose snapper Lutjanus guttatus (Lutjanidae) from Mazatlan Bay, Mexico. Fol. Parasitol. 59: 53-58.

Thatcher V. E. 2006. Amazon fish parasites. Pensoft, Sofia, 508p.

Thatcher, V.E. \& Kritsky, D.C. 1983. Neotropical Monogenoidea. 4. Linguadactyloides brinkmanni gen. et sp. n. (Dactylogyridae: Linguadactyloidinae subfam n.) with observations on its pathology in a Brazilian freshwater fish, Colossoma macropomum (Cuvier). Proc. Helminth. Soc. Wash. 50: 305-311. Varella, A.M.B; Peiro,S.N. \& Malta, J.C.O. 2003. Monitoramento da parasitofauna de Colossoma macropomum, cultivado em tanques-rede em um lago de várzea na Amazônia, Brasil. In: Simpósio Brasileiro de Aquicultura, 12, Goiânia, V.2, p.95-106.
Submetido: Novembro/2011 Revisado: Novermbro/2012 Aceito: Novembro/2012 